This is an informal report intended primarily for internal or

UCID - 16536 limited external distribution. (The opinions and conclusions stated are those of the author and may or may not be those of the laboratory.) This report is not to be given additional external distribution or cited in external documents without the consent of the author or LLL Technical Information Department.

\author{
近 \\ LAWRENCE LIVERMORE LABORATORY \\ University of California/Livermore, California

\section{UNDERGROUNDING OF NUCLEAR REACTORS \\ BY OPEN PIT EXCAVATION}

D. WOOSTER

February 13, 1973

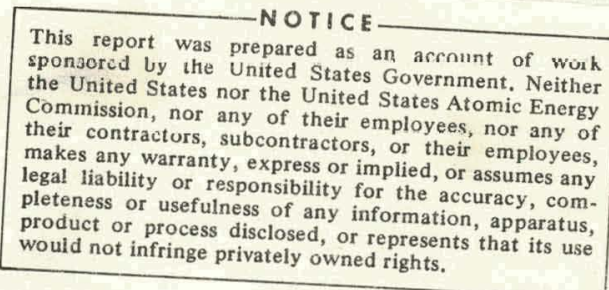




\section{DISCLAIMER}

This report was prepared as an account of work sponsored by an agency of the United States Government. Neither the United States Government nor any agency Thereof, nor any of their employees, makes any warranty, express or implied, or assumes any legal liability or responsibility for the accuracy, completeness, or usefulness of any information, apparatus, product, or process disclosed, or represents that its use would not infringe privately owned rights. Reference herein to any specific commercial product, process, or service by trade name, trademark, manufacturer, or otherwise does not necessarily constitute or imply its endorsement, recommendation, or favoring by the United States Government or any agency thereof. The views and opinions of authors expressed herein do not necessarily state or reflect those of the United States Government or any agency thereof. 


\section{DISCLAIMER}

Portions of this document may be illegible in electronic image products. Images are produced from the best available original document. 


\begin{tabular}{|l|l|l|}
\hline ENGINECT UNDERGROUNDING OF NUCLEAR REACTORS BY OPEN & \multicolumn{1}{|c|}{ ENN 73-30 1} \\
\hline PIT EXCAVATION & NAME D. Wooster \\
\hline SUATE February 13,1973
\end{tabular}

It has been proposed that the primary reactor circuits of commercial nuclear reactor power plants be placed underground.

The space requirement would consist of a cylindrical room $180^{\prime}$ in height and $90^{\prime}$ in diameter. Bottom of the room would be at $400^{\prime}$ depth.

For full safety it is thought that the room must have a support shell capable of supporting lithostatic pressure, regardless of the competency of geologic stratum involved.

Several openings from the surface to the room would also be needed for circulation of fluids, service access, etc.

To develop such a complex by underground mining techniques is possible; but expensive. Also, emplacement of equipment of the dimensions and weights envisioned through any reasonabiy sized access shaft becomes complicated and costly.

In view of the above, perhaps excavation of a large hole to the desired depth, allowing ready 1 acement of the reactor room support structure and equipment, becomes feasible. Of added interest would be the easy installation of access shaft lining, piping, etc., during the stemming operation. A sealing layer of clay or other material to aid in isolation of the reactor from the surrounding media could be placed if desired.

Burial of the "surface" plant at shallow depth would come naturally, if desired.

The following cost estimates are based on a model providing a general excavation to $265^{\prime}$ depth with slope angles of $45^{\circ}$ for competent rock and $30^{\circ}$ for earth. A work area $210^{\prime}$ in dia. is provided at the bottom of this excavation and a $110^{\prime}$ hole $135^{\prime}$ in depth with vertical walls to contain the reactor room support structure is located at center point, though it could readily be located off center to provide a better equipment and work area at the $265^{\prime}$ level.Access would be by spiral road way used in making the excavation.

Cost estimates are based on current practice and bids - see attached sheet from the Dodge Estimating Guide. Also, a recent excavation bid of 1.75 per yd of competent sands tone at Trinidad, Colorado was recorded.

For this note, a figure of $\$ 2.25$ per yd of rock, and $\$ 1.00$ per yd for earth will be used. You will also note this corresponds to excavation slope angles of $45^{\circ}$ and $30^{\circ}$. For intermediate materials, intermediate slope angles (with intermediate volumes) and intermediate unit excavation costs are envisioned. In other words, total costs should average out between the 2 end limits, in nearly all locations. Material replacement is estimated at $\$ 1.00$ for rock and .75 for earth.

Cost for excavation of the $110^{\prime} \times 135^{\prime}$ bottom hole is estimated at 10.00 per yd for both rocks and earth - Earth digs easier; but needs more wall support, during excavation. 


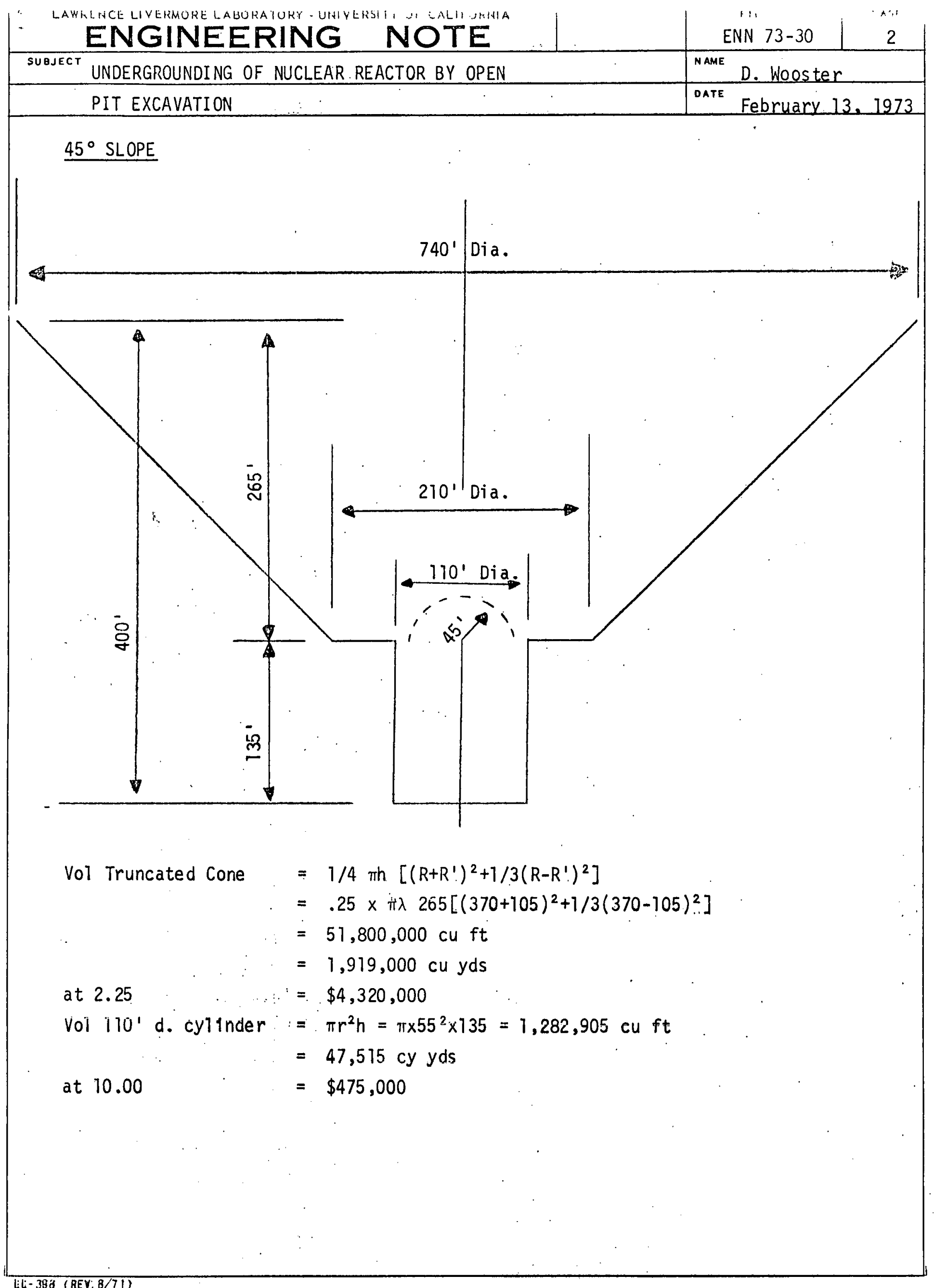




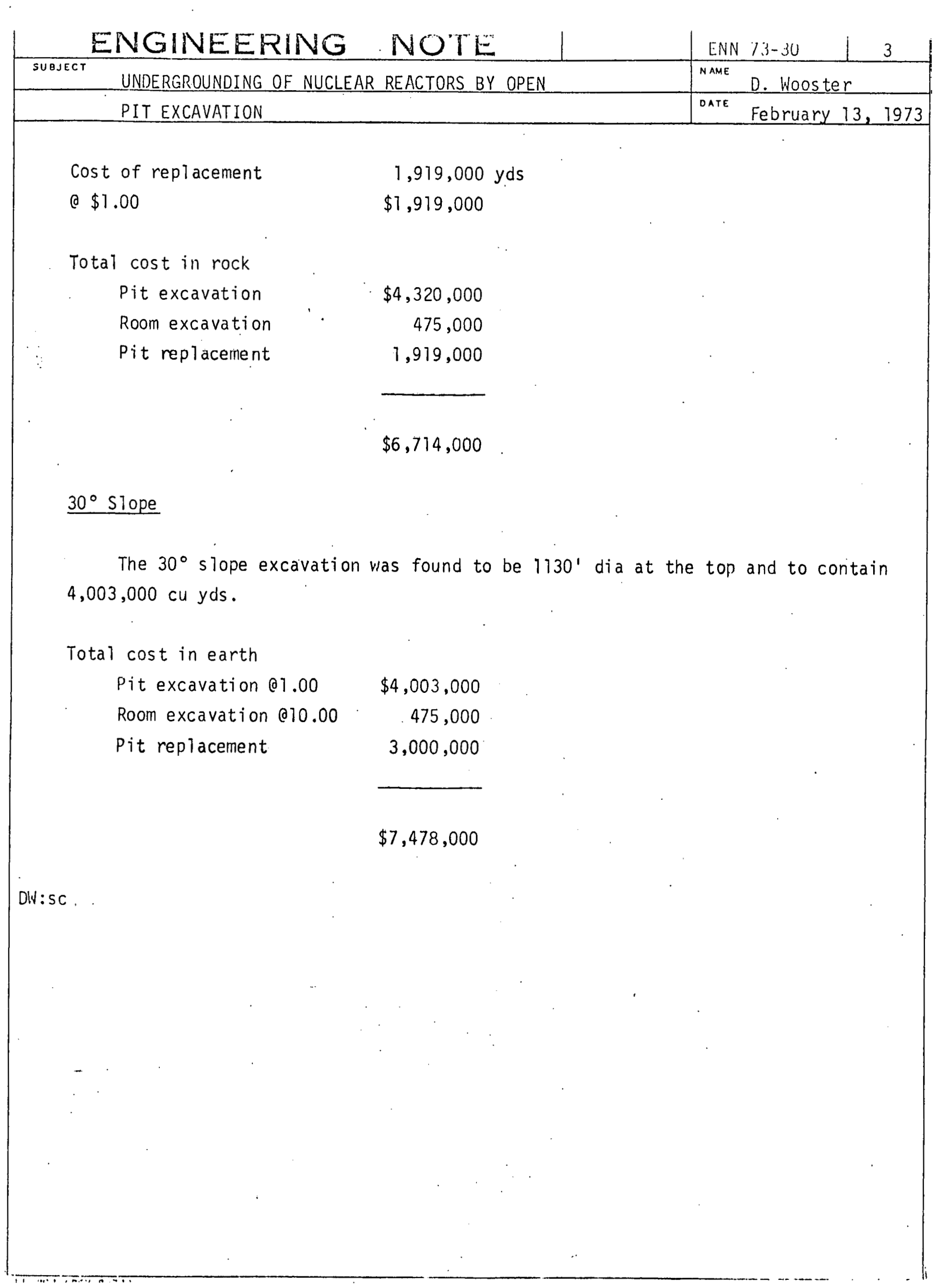




\section{DIS'LIRTBU'ION}

LLL Internal Distribution

TID File

Externai Distribution

Donna Grossman

Cerritos Colliege, Norwatk, CA.

Willian A. Loweth

Box. 709, Johnson Hall.

New York, N. Y.

USAEC, Technical Information Center,

Oak Ridge, Tennessee

NoTicl:

"This report was proparted ats an accoum of work sponsored by llice Uniled Siates Government. Neillher the United Stales nor lle Unjed Siales Alomic Encrby Commission, nor any of lheir

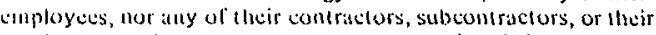

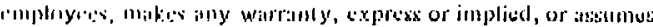

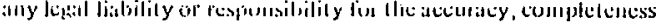

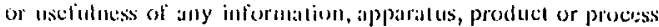
disclused, or represents thal ils use would not inlringe privatelyowised rights." 